\title{
STRATEGI PROMOSI AIR MINUM DALAM KEMASAN (AMDK) AL QODIRI
}

\author{
SAMPIR ANDREAN SUKOCO* \\ Program Studi Ilmu Administrasi Niaga \\ Sekolah Tinggi Ilmu Administrasi Pembangunan Jember \\ *Email: andresukocostia@gmail.com
}

\begin{abstract}
ABSTRAK
Promosi merupakan usaha yang dapat dilakukan untuk mempengaruhi, menciptakan permintaan atas produk dengan tujuan menciptakan daya tarik yang cepat terhadap pelanggan. Promosi akan berjalan dengan baik apabila pesan yang disampaikan sesuai dengan keinginan para pelanggan. Penelitian ini bertujuan untuk mengetahui strategi promosi yang dilakukan PT Tujuh Impian Bersama. Metode penelitian ini menggunakan metode kualitatif studi kasus dengan cara mendeskripsikan apa yang dilakukan perusahaan dalam strategi promosi yaitu program pemberian hadiah untuk menarik pelanggan baru mauapun pelanggan lama. Teknik penentuan informan menggunakan metode purposive, informan untuk penelitian ini berjumlah 3 orang yang dipilih peneliti karena memiliki kompetensi dibidangnya. Pengumpulan data dilakukan melalui observasi, wawancara, dokumentasi, dan triangulasi.

Metode analisis data dilakukan dengan tiga cara yaitu reduksi data, penyajian data, dan penarikan kesimpulan. Kesimpulan yang didapat dalam penelitian ini adalah PT Tujuh Impian Bersama menggunakan strategi promosi undian berhadiah untuk meningkatkan penjualan air minum dalam kemasan al qodiri yang dilakukan satu tahun sekali.
\end{abstract}

Kata Kunci: Strategi, Promosi, AMDK Al Qodiri 


\section{PENDAHULUAN}

Bisnis merupakan kegiatan yang ada pada aktivitas kita sehari-hari. Produk-produk yang kita gunakan dalam kehidupan sehari-hari merupakan kegiatan bisnis yang dilakukan oleh pencipta produk atau orang-rang yang melakukan bisnis. Produk bisnis selalu kita pakai, seperti contoh dimulai dari bangun tidur kita minum air menggunakan air minum dalam kemasan, mandi menggunakan sabun mandi, berangkat bekerja menggunakan kendaraan. Semua itu merupakan hasil dari kegiatan bisnis yang kita konsumsi.

Manusia merupakan makhluk sosial yang membutuhkan orang lain untuk bertahan hidup termasuk untuk kegiatan bisnis. Kita bukan pencipta produk, tetapi minimal kita menggunakan dari hasil-hasil produksi orang lain. Hal tersebut dapat dikatakan bahwa kita masuk dalam kegiatan bisnis walaupun kita hanya sebagai konsumen. Bisnis memiliki syarat sederhana yaitu adanya produk yang di tawarkan atau dihasilkan, dan terdapat orang-orang yang membeli dari produk tersebut.
Kita menyadari bahwa semakin lama kegiatan bisnis semakin diminati. Kegiatan bisnis atau berbisnis dianggap bisa memberikan kepuasan material dan non materi. Lapangan pekerjaan yang terbatas dan angka pemutusan hubungan kerja yang semakin tinggi menjadikan bisnis menjadi alternatif yang sangat digemari. Memang ada yang sukses dengan kegiatan bisnisnya tapi juga ada yang belum sukses (Suhendi \& Sasangka, 2014:1).

Bisnis memang tidak terlepas dari persaingan-persaingan yang keras. Terlebih saat ini dunia bisnis memang semakin digemari. Fenomena yang ada saat ini banyak pegawai-pegawai perusahaan yang keluar/mengundurkan diri dari perusahaannya untuk membuka bisnis sendiri. Tidak sedikit juga yang akhirnya menjadi sukses.

Negara yang semakin maju tentu memiliki kualitas sumber manusia yang terdidik, dan banyak pula orang yang menganggur, maka semakin dirasakan pentingnya dunia wirausaha. Pembangunan akan lebih 
berhasil jika ditunjang oleh wirausahawan yang dapat membuka lapangan kerja karena kemampuan pemerintah sangat terbatas. Pemerintah tidak akan mampu menggarap semua aspek pembangunan karena sangat banyak membutuhkan anggaran belanja, personalia, dan pengawasan. Oleh sebab itu, wirausaha merupakan potensi pembangunan, baik dalam jumlah maupun dalam mutu wirausaha itu sendiri. Suatu pernyataan yang bersumber dari PBB menyatakan bahwa suatu negara akan mampu membangun apabila memiliki wirausahawan sebanyak $2 \%$ dari jumlah pendudukya. Jadi, jika negara kita berpenduduk 200 juta jiwa, maka wirausahannya harus lebih kurang sebanyak 4 juta (Alma, 2013:1).

Perusahaan-perusahaan baru banyak mulai bermunculan dengan produk masing-masing yang ditawarkan. Fenomena tersebut menarik untuk dikaji, baik dari sisi produk, harga, dan strategi promosinya. Perusahaan berlombalomba menjalankan strateginya untuk menarik hati konsumen. Konsumen saat ini semakin diuntungkan karena dapat memilih dengan leluasa macam-macam produk yang ditawarkan sesuai dengan keinginan dan kebutuhannya. Bertolak belakang dengan keuntungan yang diperoleh konsumen, saat ini perusahaan akan semakin bekerja keras untuk menghadapi pesaingpesaing baru.

Strategi bersaing yang tepat adalah cara bagi perusahaan untuk mendapatkan dan mempertahankan konsumen. Promosi merupakan salah satu cara yang dapat dilakukan oleh perusahaan. Promosi yang sesuai dengan minat konsumen akan menimbulkan efek pembelian suatu produk. Pada saat ini, rata-rata semua perusahaan bisnis banyak yang sudah melakukan strategi promosi untuk menawarkan produknya.

Pemasaran yang berdaya saing merupakan wujud kesuksesan sebuah strategi pemasaran. Sebagai sebuah entitas, ada kesamaan antara inidividu, organisasi, dan perusahaan, masing-masing memiliki kebutuhan yang besar untuk menjaga keberlanjutannya. Daya saing sangat diperlukan oleh setiap entitas berada 
yang dalam keadaan saling berkompetisi ketat dengan para kompetitor. Masing-masing harus memiliki keunggulan yang dapat menjadi bahan pertimbangan (Purwanto, 2012 : 3).

Produk Air Minum Dalam Kemasan (AMDK) di Indonesia dewasa ini semakin berkembang, tentu masing-masing perusahaan AMDK akan bekerja keras dalam memenangkan persaingan. Belum lagi ditambah AMDK lokal yang banyak bermunculan dengan harga yang sangat terjangkau. Perusahaan AMDK lokal juga sudah tidak sedikit yang melakukan strategi-strategi pemasaran yang sangat baik. Bisnis AMDK semakin tumbuh karena kebutuhan air minum semakin meningkat seiring dengan pertumbuhan penduduk. Perusahaan yang menggarap bisnis air minum dalam kemasan pun semakin banyak dan terus melakukan ekspansi untuk memperluas jaringan pasar-pasar produknya (Juniar, 2010 : 39).

Produk AMDK dahulu yang kita kenal mungkin hanya air minum dalam kemasan merek Aqua. Kemunculan AMDK pertama di
Indonesia tidak lepas dari sejarah produk bermerek Aqua. Sebab Aqua menjadi produk AMDK pertama yang diproduksi di Indonesia. Aqua adalah salah satu brand AMDK yang cukup terkenal dan mampu menjadi raja untuk produk-produk AMDK. Aqua ini di produksi oleh Aqua Golden Missisipi di Indonesia dari tahun 1973. Pemilik Aqua adalah Tirto Utomo, sebelum di akuisisi oleh Danone pada tahun 1998. Kesuksesan Aqua tidak hanya menggema di dalam negeri saja, tapi juga beberapa negara tetangga seperti Malaysia, Thailand, Singapura, Australia, dan lain-lain. Aqua sempat dinobatkan sebagai merk AMDK terbesar di Asia Pasifik, dan juga AMDK nomor dua terbesar di dunia (Afram, 2012: 223).

Produk AMDK di Kabupaten Jember yang baru-baru ini mulai dikenal masyarakat Jember adalah AMDK AL Qodiri yang diproduksi oleh PT Tujuh Impian Bersama. Perusahaan ini beroperasi sejak tahun 2012. AMDK Al Qodiri terus mengalami perkembangan dari yang semula hanya ditujukan untuk pemenuhan kebutuhan air minum 
Jamaah Pengajian Manakib di Pondok Pesantren Al Qodiri menjadi jauh lebih luas dengan melayani konsumen umum.

AMDK Al Qodiri sudah banyak tersedia di banyak toko. Produk AMDK Al Qodiri sudah tersebar diberbagai Kabupaten diantaranya Jember, Lumajang, Banyuwangi, Bondowoso, dan Situbondo. AMDK Al Qodiri juga mampu menembus sebagian wilayah Jawa Timur yaitu Pasuruan, Madura dan wilayah Bali, bahkan produk ini sudah masuk dalam ritel Indomart dan Alfamart seluruh Karisidenan Besuki. Satusatunya produk AMDK lokal Jember yang masuk Indomart dan Alfamart di Karisidenan Besuki. Harganya juga cukup terjangkau, lebih murah dibandingkan beberapa produk AMDK yang sudah skala Nasional. Harga yang lebih murah tersebut, tentu produk AMDK Al Qodiri

\section{TINJAUAN PUSTAKA}

\subsection{Strategi}

Seseorang yang terlibat dalam bisnis, khususnya pemasaran, tentunya akan berhadapan dengan lingkungan persaingan yang amat menjadi pesaing lokal yang di perhitungkan oleh produk AMDK skala Nasional.

PT Tujuh Impian Bersama selaku perusahaan yang memproduksi AMDK Al Qodiri selalu menunjukkan eksistensinya dalam kegiatan promosi jika dilihat dari strategi penjualannya. Berkembangnya perusahaan tentu diikuti oleh strategi pemasaran yang baik. Khususnya strategi promosi yang dilakukan. Uraian tersebut menjadi latar belakang dilakukannya penelitian Strategi Promosi Air Minum Dalam Kemasan (AMDK) Al Qodiri.

Berdasarkan latar belakang uraian permasalahan diatas, maka yang menjadi pokok masalah adalah: "Bagaimana strategi promosi Air Minum Dalam Kemasan (AMDK) Al-Qodiri yang dilakukan oleh PT Tujuh Impian Bersama".

dinamis. Perubahan lingkungan yang dinamis ini seringkali gagal diantisipasi dengan baik oleh para pelaku bisnis, sehingga banyak sekali perusahaan yang punya nama besar 
berjatuhan karena gagal mengantisipasinya. Sebelum masuk lebih jauh dalam pembahasan tentang strategi pemasaran, maka perlu terlebih dahulu dipahami tentang makna strategi itu sendiri. Strategi sebagai sebuah kosa kata pada mulanya berasal dari bahasa Yunani, yaitu "strategia" atau sering disebut sebagai strategos. Kata strategos ini berasal dari kata "stratos" yang berarti militer dan “ag” yang artinya memimpin (Purnomo dan Zulkieflimansyah, 2005: 8).

Kusdi (2011: mendefinisikan strategi sebagai penetapan berbagai tujuan dan sasaran jangka panjang yang bersifat mendasar bagi sebuah organisasi, yang selanjutnya dikembangkan melalui perencanaan aktivitas dan pengalokasian sumber daya yang diperlukan guna mencapai sasaransasaran tersebut. Strategi dapat berupa perencanaan yang detail dan sistematis di awal kegiatan (planning mode), tetapi dapat pula berupa proses evolusioner secara bertahap sesuai dengan kondisi dan situasi yang dihadapi organisasi.
Strategi harus dirancang secara kreatif, dengan menggali segala sesuatu di balik fakta dan menyusunnya ke arah gagasan kreatif yang mampu menciptakan penjualan. Strategi kreatif bukan semata-mata proses logika, tetapi juga menyangkut seni. Namun demikian, untuk memperoleh strategi yang dapat di gunakan, strategi harus dibuat berdasarkan fakta. Strategi harus dirancang secara kreatif, dengan menggali segala sesuatu di balik "insight" dan menyusunnya ke arah gagasan kreatif, seperti bentuk kreativitas berupa suatu tindakan yang merupakan hasil pemikiran yang sadar maupun setengah sadar yang berupa pengetahuan, logika, imajinasi, dan intuisi. Secara sederhana, merencanakan strategi kreatif pemasaran adalah proses membuat strategi untuk mencapai tujuan. Tujuan pokok strategi kreatif periklanan atau pemasaran adalah agar pemasaran dapat membentuk komunikasi pemasaran yang lebih kreatif sehingga berhasil meraih tujuan sebagaimana yang di harapkan secara maksimal (Kertamukti, 2015: viii). 
Purwanto (2012) berpendapat bahwa strategi memiliki determinandeterminan umum yang terdiri dari komponen-komponen yang dibahas, yaitu:

1. Tujuan dan sasaran, perlu dipahami bahwa tujuan berbeda dengan sasaran. Harvey mencoba menjelaskan keduanya, bahwa organizational goals adalah keinginan yang hendak dicapai di waktu yang akan datang, yang digambarkan secara umum dan relatif tidak mengenal batas waktu, sedangkan organizational objectives adalah pernyataan yang sudah mengarah pada kegiatan untuk mencapai goals karena lebih terikat waktu, dapat diukur dan dapat dijumlah atau dihitung.

2. Lingkungan, harus disadari bahwa organisasi tidak hidup dalam isolasi. Seperti halnya manusia organisasi juga digerakkan oleh manusia yang senantiasa berinteraksi dengan lingkungannya, dalam arti saling mempengaruhi.

3. Kemampuan internal, kemampuan internal oleh Shirley digambarkan sebagai apa yang dapat dibuat (can do) karena kegiatan akan terpusat pada kekuatan.

4. Kompetisi, kompetisi ini tidak dapat diabaikan dalam merumuskan strategi.

5. Pembuat strategi, ini juga penting karena menunjuk siapa yang kompeten membuat strategi.

6. Komunikasi, para penulis secara implisit menyadari bahwa melalui komunikasi yang baik, strategi bisa berhasil.

\subsection{Promosi}

Promosi adalah kegiatan komunikasi persuasif. Dalam kehidupan sehari-hari manusia tidak pernah bisa lepas dari kegiatankegiatan persuasi, hal ini karena seseorang memiiki keinginan atau maksud-maksud tertentu yang terkadang melibatkan suatu kegiatan 
persuasi untuk dapat mempengaruhi bahkan mengajak orang lain untuk sepakat dan mau melakukan maksud dan keinginannya tersebut. Komunikasi persuasif menurut Barata (2003: 70) adalah penyampaian pesan terhadap khalayak banyak dengan tujuan (membujuk, merayu, mengajak) untuk mengikuti apa yang di sampaikan. Biasanya komunikasi persuasif mudah kita ditemui pada iklan.

Perusahaan saling berkompetisi untuk menguasai pangsa pasar yang ada, yaitu dengan cara membuat perencanaan pemasaran yang baik demi mendapat pencitraan yang positif di benak konsumen. Pihak manajemen di masing-masing perusahaan juga dituntut agar dapat meningkatkan dan mempertahankan pelanggan yang ada. Selain itu keberhasilan perusahaan dalam mencapai kinerja yang optimal secara terus-menerus ditentukan oleh seberapa besar perusahaan mampu untuk berinovasi agar dapat terus bertahan dan berkompetisi dalam dunia bisnis. Strategi pemasaran yang tepat dan terencana bukan hanya diterapkan di perusahaan besar tetapi industri rumahan juga menetapkan strategi yang sama konsumen, kualitas produk, serta penyampaian tentang keunggulan produk yang dihasilkan dalam bentuk promosi untuk menciptakan kepuasan di benak konsumen (Lasander, 2013: 29).

Marwanto dalam bukunya (2015: 24) menjabarkan kelima bentuk promosi diantaranya:

1. Promotion by product (promosi dengan produk), sebagai contoh, beli dua gratis satu, laundry lima kali gratis laundry satu kali.

2. Promotion by material (promosi dengan uang), sebagai contohnya voucher potongan harga, harga grosir, dan lain-lain.

3. Promotion by customer satisfaction (promosi dengan kepuasan pelanggan), sebagai contoh, garansi diperpanjang, garansi purna jual, bisa ditukar bila kurang puas.

4. Promotion by achievement (promosi dengan prestasi) 
sebagai contoh, dalam

kemasan produk di

cantumkan sertifikat ISO,

standart SNI, penerima

penghargaan rekor MURI,

dan lain sebagainya.

5. Promotion by recognition (promosi

dengan

pengakuan) sebagai

contohnya adalah sertifikat halal, penjualan terlaris, dan lain sebagainya.

Kegiatan promosi menurut Suwarno (2011: 196) adalah usaha mempengaruhi konsumen, untuk menciptakan permintaan atas produk, kemudian dipelihara dan dikembangkan, yang merupakan salah satu dari acuan/bauran pemasaran (marketing mix) sehingga dapat meningkatkan penjualan dan share pasar, serta mempertahankan ketenaran merk/brand. Tidak terlepas dari kebijakan marketing mix lainnya sebagai satu kesatuan dan merupakan penggunaan kombinasi yang terdapat dalam unsur-unsur peralatan promosi, terdiri dari:
1. Advertising (Periklanan)

Merupakan suatu bentuk penyajian dan promosi gagasan, barang, atau jasa yang dibiayai oleh suatu soponsor tertentu, bersifat non personal dan menggunakan media, seperti radio, televisi, surat kabar, dan lain-lain. Periklanan merupakan alat utama bagi produsen untuk mempengaruhi konsumennya.

2. Personal Selling (Penjualan Pribadi)

Merupakan penyajian secara lisan dalam suatu pembicaraan dengan seseorang atau lebih calon pembeli dengan tujuan agar dapat terealisasinya penjualan. Personal selling bersifat penuh dengan interaksi, dan adanya tanggapan langsung dari komunikator dan komunikan. Penjualan pribadi merupakan kegiatan perusahaan untuk melakukan kontak langsung dengan calon konsumennya. 
Jenis kegiatan personal

selling antara lain : door to door selling, telephone selling, dan direct selling.

3. Sales

Promotion

(Promosi Penjualan)

Merupakan segala

kegiatan pemasaran selain

personal selling, advertensi, dan publisitas, yang merangsang pembelian oleh konsumen dan keefektifan agen seperti pemasaran, pertunjukan, demontrasi dan segala usaha penjualan yang tidak dilakukan secara teratur atau kontinyu. Promosi penjualan dapat dikatakan kegiatan perusahaan untuk menjajakan produk yang dipasarkan sedemikian rupa sehingga konsumen akan mudah untuk melihatnya dan bahkan dengan cara penempatan dan pengaturan tertentu, maka produk tersebut akan menarik perhatian konsumen.

4. Publisitas

Merupakan usaha untuk merangsang permintaan dari suatu produk secara non personal dengan membuat, baik berupa berita bersifat komersial tentang produk tersebut di dalam media tercetak atau tidak, maupun hasil wawancara yang disiarkan dalam media tersebut. Publisitas merupakan cara yang biasa digunakan juga oleh perusahaan untuk membentuk pengaruh secara tidak langsung kepada konsumen, agar mereka menjadi tahu, dan menyenangi produk yang dipasarkannya, hal ini berbeda dengan promosi dimana didalam melakukan publisitas perusahaan tidak melakukan hal yang bersifat komersial. Publisitas merupakan alat promosi yang mampu membentuk opini masyarakat secara tepat, sehingga sering disebut sebagai usaha untuk mensosialisasikan atau memasyarakatkan suatu objek tertentu. 


\section{METODE PENELITIAN}

\section{Jenis Penelitian}

Berdasarkan permasalahan dan tinjauan peneliti, maka tipe penelitian ini menggunakan penelitian kualitatif pendekatan studi kasus dengan data deskriptif. Moleong (2016 : 11) yang menjelaskan bahwa data deskriptif sebagai, "Data yang dikumpulkan berupa kata-kata, gambar, dan bukan angka". Dengan demikian data dalam penelitian ini sebagian besar berasal dari naskah wawancara, catatan lapangan, foto, dan dokumen resmi lainnya yang berhubungan dengan bentuk promosi AMDK AL-Qoodiri.

\section{Penentuan Informan}

Menurut Sugiyono (2015: 53) dalam penelitian kualitatif, teknik sampling yang dapat digunakan adalah purposive sampling. Metode ini merupakan teknik pengambilan sampel sumber data dengan pertimbangan tertentu. Pertimbangan tertentu ini, misalnya orang tersebut yang dianggap paling tahu tentang apa yang kita harapkan, atau mungkin dia sebagai penguasa sehingga akan memudahkan peneliti menjelajahi obyek atau situasi sosial yang diteliti. Informan dalam penelitian ini terdiri dari 3 informan diantaranya kepala divivi bisnis, kepala departemen sales \& distribusi, dan kepala departemen marketing.

\section{Teknik Pengumpulan Data}

Sugiyono (2016:

menyebutkan bahwa tanpa mengetahui teknik pengumpulan data, maka peneliti tidak akan mendapatkan data yang memenuhi standart data yang di tetapkan. Pengumpulan data dapat dilakukan dalam berbagai setting, berbagai sumber, dan berbagai cara. Dalam tahap ini langkah-langkah yang dilakukan penulis adalah sebagai berikut :
a. Observasi
b. Wawancara
c. Dokumentasi
d. Triangulasi

\section{Analisis Data}

Analisis data kualitatif menurut Bogdan dan Biklen yang disitir Moleong (2016 : 248) adalah, upaya bekerja dan mengorganisasikan data, memilah-milahnya menjadi satuan yang dapat dikelola, mensintesiskannya, mencari dan 
menemukan pola yang penting dan yang dipelajari. Penelitian ini nantinya menggunakan analisis yang terdiri dari tiga alur yang terjadi secara bersamaan yaitu reduksi data, penyajian data, dan penarikan kesimpulan/verifikasi.

\section{HASIL PENELITIAN DAN PEMBAHASAN}

\subsection{Sejarah dan Perusahaan}

Identitas perusahaan (corporate identity) adalah suatu cara atau suatu hal yang memungkinkan suatu perusahaan dikenal dan dibedakan dari perusahaan-perusahaan lainnya. Identitas perusahaan tersebut harus diciptakan melalui suatu rancangan desain khusus yang meliputi segala hal khas/unik berkenaan dengan perusahaan yang bersangkutan secara fisik. Desain tersebut, memiliki wujud sedemikian rupa sehingga dapat mengingatkan khalayak akan perusahaan tertentu. Identitas perusahaan memiliki elemen-elemen utama yang meliputi warna, bentuk bangunan, tipe logo, atribut, sampai dengan seragam dan pakaian resmi perusahaan. Identitas perusahaan sesungguhnya merupakan salah satu bentuk tertua dari komunikasi yang didasarkan pada suatu rancangan tertentu dan senantiasa terarah pada tujuan-tujuannya. (Jefkins, 1995: 296).

Air Minum Dalam Kemasan (AMDK) Al Qodiri diproduksi oleh PT Tujuh Impian Bersama. Perusahaan ini beroperasi sejak tahun 2012. AMDK Al Qodiri terus mengalami perkembangan dari yang semula hanya ditujukan untuk pemenuhan kebutuhan air minum Jamaah Pengajian Manakib di Pondok Pesantren Al Qodiri menjadi jauh lebih luas dengan melayani konsumen umum. AMDK Al Qodiri adalah produk dibawah pengelolaan Manajemen CV Seven Dream Air Al Qodiri yang dalam kurun waktu 5 tahun ini terus mengalami pengembangan. Pada mulanya perusahaan ini berbentuk $\mathrm{CV}$ dan tahun 2015 sudah berganti menjadi PT, yaitu PT Tujuh Impian Bersama.

Perkembangan tersebut tidak terlepas dari adanya tuntutan sehingga manajemen terus berusaha 
meningkatkan kapasitas produksi dan layanan kepada konsumen dengan salah satunya peningkatan status badan usaha menjadi PT Tujuh Impian Bersama.

Inovasi dan kualitas produk yang menjadi fokus utama membuat produk AMDK Al Qodiri diterima oleh masyarakat Jember dan bahkan pada perkembangannya saat ini telah mencapai Karisidenan Besuki dan sekitarnya. Keseriusan tersebut dijawab oleh perusahaan PT Tujuh Impian Bersama dengan kemudian melanjutkan perkembangan dalam rangka meningkatkan mutu produk dan layanan kepada pelanggan dengan diperolehnya Sertifikat Manajemen Mutu ISO 2008 pada tahun 2016 .

\subsection{Strategi Promosi AMDK Al Qodiri}

Promosi merupakan strategi utama untuk mengenalkan AMDK AL Qodiri terhadap konsumen. Strategi promosi selalu digunakan sebagai salah satu cara untuk meningkatkan permintaan atau penjualan AMDK Al Qodiri, selain itu promosi adalah kegiatan yang dijadikan cara PT Tujuh Impian Bersama untuk berkomunikasi langsung dengan konsumen maupun calon konsumen. Rusdiyanto selaku Kepala Divisi Bisnis PT Tujuh Impian Bersama menyatakan bahwa promosi adalah alat untuk menarik pelanggan.

Slamet Sucahyo selaku General Manager PT Tujuh Impian Bersama juga membuat pernyataan yang sama tentang fungsi dari promosi, yaitu agar produk dapat diterima disisi masyarakat. Promosi merupakan alat yang efektif untuk melakukan persuasif pada masyarakat. Semakin gencar melakukan promosi maka produk AMDK Al Qodiri semakin dikenal dan diharapkan meningkatkan penjualan.

Tantangan terbesar dalam menyusun strategi promosi yang kreatif dan membuat program promosi dalam bentuk suatu komunikasi adalah menentukan strategi dan program promosi mana yang paling efektif untuk menghasilkan dampak yang besar terhadap penjualan produk. PT Tujuh Impian Bersama selaku perusahaan yang memproduksi AMDK Al 
Qodiri juga demikian. Menentukan strategi promosi untuk memenangkan persaingan.

Alat promosi sangat beraneka ragam, salah satunya adalah dengan promosi penjualan. Promosi penjualan bekaitan dengan insentif dan hadiah untuk membuat para pelanggan tertarik untuk membeli produk yang ditawarkan. Alat promosi penjulan ini sifatnya relatif untuk jangka pendek jika dibandingkan dengan strategi penggunaan iklan yang memiliki jangka waktu yang lebih panjang. PT Tujuh Impian Bersama menggunakan strategi promosi penjualan untuk mendongkrak penjualan. Strategi tersebut berupa undian.

Konsumen membeli produk pada dasarnya adalah karena kebutuhan, tetapi tidak dipungkiri bahwa strategi promosi yang tepat akan dapat merayu konsumen untuk membeli produk. Konsumen yang awalnya tidak tertarik untuk membeli suatu produk bisa terbujuk oleh promosi yang menarik perhatian. Artinya adalah tendensi pembelian, terjadi tidak hanya karena kebutuhan bagi konsumen, tetapi juga seringkali disebabkan oleh penyertaan penawaran yang memberikan nilai tambah bagi pelanggan. PT Tujuh Impian Bersama melakukan strategi promosi tersebut.

Promosi penjualan (undian)
yang dilakukan yaitu program
berhadiah. Hadiah yang ditawarkan
dapat dilihat pada tabel.

Tabel 1. Program Undian Berhadiah

\begin{tabular}{ccl}
\hline No & Jumlah Hadiah & \multicolumn{1}{c}{ Jenis Hadiah } \\
\hline 1 & 17 & Paket Umroh / Singapura (boleh pilih) \\
2 & 17 & Motor Matic \\
3 & 17 & TV LED 24" \\
4 & 17 & Emas Murni 24 karat \\
5 & 1.700 & Voucher Diskon \\
\hline
\end{tabular}

Sumber : PT Tujuh Impian Bersama, 2017

Hadiah yang ditawarkan ada 5 jenis, yaitu paket umroh/jalan-jalan ke Singapura. Total untuk jenis ini ada 17. Jenis undian yang kedua adalah pemenang akan mendapatkan 17 motor matic. PT Tujuh Impian 
Bersama menawarkan undian ketiga TV LED dengan jumlah yang sama yaitu 17 buah. Untuk jenis hadiah yang keempat PT Tujuh Impian Bersama menawarkan Emas Murni 24 karat, sedangkan untuk hadiah terakhir adalah 1700 Voucher Diskon.

Paket undian tersebut dalam satu tahun dilakukan dengan periode pengundian 3 bulan sekali, Tujuan dilakukan program undian ini dengan periode pengundian 3 bulan sekali adalah dengan pertimbangan mengikuti ritme pasar yang dinilai produk yang dikeluarkan di pasaran bisa terjual dan terkumpul kembali berupa kupon undian dalam jangka waktu 3 bulan. Selain itu menyesuaikan dengan penetrasi pasar yang tujuannya meningkatkan pasar, mempertahankan pasar yang sudah ada atau stabilitas pasar, serta merupakan bentuk kampanye produk yang konsisten.

Penggunaan strategi promosi penjualan ini dapat menarik langsung konsumen untuk membeli dan mengikuti program promosi tersebut terutama pelanggan setia AMDK Al Qodiri. Selain itu, strategi yang dirancang adalah agar orang yang tidak ingin membeli diharapkan tertarik karena program undian tersebut. Oleh karena itu, aktivitas promosi penjualan tersebut secara langsung akan memberikan dampak membentuk keramaian (traffic builder), dan juga membuka ruang bagi pelanggan baru sekaligus menjadi sarana membentuk referensi pada pelanggan setia.

Undian mendorong konsumen potensial bersaing memperebutkan hadiah atau mencoba beradu peluang dengan menyerahkan nama untuk diundi dalam memperebutkan hadiah. Undian baik sekali untuk menarik sejumlah besar peserta dan ketertarikan yang luas terhadap produk AMDK Al Qodiri karena tidak membutuhkan keterampilan untuk mengikuti undian. Berbeda dengan kontes yang mana peserta harus memiliki keunggulan tersendiri, maka undian sifatnya adalah peruntungan. Siapapun bisa mendapatkan hadiah tanpa harus memiliki keterampilan tertentu. Hal inilah yang menjadi daya tarik dari program undian berhadiah yang 
dilakukan oleh PT Tujuh Impian Bersama.

Penjualan dari AMDK Al Qodiri juga terus mengalami kenaikan. Menurut Rusdiyanto selaku Kepala Divisi Bisnis Tujuh Impian Bersama, bahwa analisis pada tahun 2017 total penjualan dari bulan per bulan rata-

\section{KESIMPULAN DAN SARAN}

\subsection{Kesimpulan}

PT Tujuh Impian Bersama menggunakan strategi promosi dengan bentuk undian berhadiah. Hadiah yang ditawarkan memiliki lima jenis, yaitu paket umroh/jalanjalan ke Singapura, Motor matic, TV LED, Emas 24 Karat, dan Voucher Diskon. Paket undian tersebut dalam satu tahun dilakukan dengan periode pengundian 3 bulan sekali.

Strategi promosi ini digunakan oleh PT Tujuh Impian Bersama untuk menarik konsumen membeli AMDK Al Qodiri. Hadiah yang ditawarkan memiliki daya tarik yang kuat untuk merayu pelanggan membeli produk AMDK Al Qodiri. Disisi lain, strategi ini juga bertujuan untuk mempertahankan pelanggan rata mengalami kenaikan kisaran 3\%-6\% hingga tutup tahun. Maka dilihat dari fenomena tersebut, dapat ditarik sebuah kesimpulan bahwa proram undian berhadiah sangat efektif untuk meningkatkan penjualan AMDK Al Qodiri.

lama agar tidak pindah ke produk AMDK lain.

\subsection{Saran}

Berdasarkan hasil kesimpulan yang diperoleh, maka masukan yang dapat direkomendasikan terkait dengan strategi promosi air minum dalam kemasan (AMDK) Al Qodiri adalah dengan menggunakan promosi jenis-jenis lain. Promosi jenis lain dapat dijadikan strategi tambahan yang pada akhirnya untuk meningkatkan penjualan, seperti beli AMDK Al Qodiri ukuran botol 1500 ml mendapat hadiah gratis AMDK Al Qodiri cup $120 \mathrm{ml}$. Saran ini hanya merupakan argumen peneliti, karena bagaimanapun strategi apa yang dilakukan merupakan 
kewenangan PT Tujuh Impian Bersama.

\section{DAFTAR PUSTAKA}

Alma, Buchari. Kewirausahaan. Bandung: Alfabeta.

Arfam. 2012. 101 Imperium Business Idea. Yogyakarta: Buku Pintar.

Barata, Atep. 2003. Dasar-Dasar Pelayanan Prima. Jakarta : PT Elex Media Komputindo.

Jefkins, Frank. 1995. Periklanan. Edisi Ketiga, Jakarta: PT Gelora Aksara Pratama.

Juniar, Asrid. 2010. Studi Kelayakan Pendirian Pabrik Air Minum Dalam Kemasan PDAM Kabupaten Hulu Sungai Utara Ditinjau Dari Aspek Keungan. Jurnal Fakultas Ekonomi Lambung Mangkurat Banjarmasin, Vol. 11, No. 1 pp. 39-45.

Kertamukti, Rama. 2015. Strategi Kreatif Dalam Periklanan. Jakarta : PT Rajagrafindo Persada.

Kusdi. 2011. Teori Organisasi dan Administrasi. Jakarta : Salemba Humanika.

Marwanto, Aris. 2015. Marketing Sukses. Yogyakarta : Kobis

Moleong, Lexy J. Metodologi Penelitian Kualitatif. Edisi Revisi. Bandung : PT Remaja Rosdakarya

Purnomo, Setiawan dan Zulkiflimansyah. 2005. Manajemen Strategi. Jakarta : Fakultas Ekonomi Universitas Indonesia.

Purwanto. 2012. Marketing Strategic Meningkatkan Pangsa Pasar \& Daya Saing. Jakarta : Platinum. 